\title{
Lyme Disease Propelled by Borrelia burgdorferi-Infected Blacklegged Ticks, Wild Birds and Public Awareness - Not Climate Change
}

\begin{abstract}
Keywords: Lyme disease; Borrelia burgdorferi; blacklegged tick; Ixodes scapularis; climate change; overwinter temperatures; songbirds; bird migration

Abstract

The blacklegged tick, Ixodes scapularis, is of major public health importance as a vector of Borrelia burgdorferi, the causal organism of Lyme disease. Migratory songbirds are involved in short- and longdistance transport of bird-feeding ticks, and play a vital role in the wide dispersal of I. scapularis and the epidemiology of Lyme disease. Because northern latitudes generally have a thick blanket of snow each winter the blacklegged tick withstands phenomenal outdoor temperature fluctuations. However, when the snow cover is lost in the core months of winter, due to subtle periods of warmer temperatures, we discovered that overwinter survival declined significantly. Photoperiod is a limiting factor in the pole-ward expansion and establishment of $I$. scapularis because immature stages of $I$. scapularis will not molt in late summer when photoperiod shortens quickly. As more and more people become aware of ticks and their associated pathogens, people submit more ticks for identification and testing. As a result, public awareness becomes a driver in the recognition of Lyme disease, and the number of human cases reported. When it comes to I. scapularis ticks, climate change is a triviality. Health professionals must be aware that Lyme disease and tickassociated diseases are a significant public health burden, and include them in their differential diagnosis.
\end{abstract}

\section{Introduction}

Lyme disease, caused by the spirochetal bacterium, Borrelia burgdorferi, is typically transmitted to humans by ixodid (hardbodied) ticks (Acari: Ixodidae) [1]. Although several tick species harbor and transmit B. burgdorferi [2,3], the blacklegged tick, Ixodes scapularis (northern populations previously considered I. dammini), is the primary vector east of the Rocky Mountains [4]. Since ticks anesthetize the skin at the bite site, patients often do not recall being bitten. In fact, $14 \%$ of Lyme disease patients remember a tick bite [5] Also, $42 \%$ or less had a bona fide erythema migrans rash and [6-8], of those with rashes, more than $50 \%$ had a homogeneous or atypical rash [6,9-12]. As the spirochete disseminates in the body, a multitude of clinical manifestations normally develop, including fatigue, flulike symptoms, muscle ache and pain, joint ache and pain, headaches, sensory loss, memory loss, and cognitive impairment [13]. Because the blacklegged tick can carry and transmit at least 10 different tickborne pathogens, Lyme disease patients may be co-infected with other zoonotic microorganisms.

The antiquity of I. scapularis in Canada is unknown. Nuttall and Warburton provide the first report of I. scapularis in Canada [14], and these females were collected from a human at Bracebridge, Ontario in 1904. Later, the developmental life stages of I. scapularis
Journal of

Veterinary Science \& Medicine

John D. Scott* and Catherine M. Scott

International Lyme and Associated Diseases Society, USA

*Address for Correspondence

John D. Scott, International Lyme and Associated Diseases Society, Bethesda, MD 20827, USA and 365 St. David Street South, Fergus, Ontario, Canada N1M 2L7, Tel: 519-843-3646; Fax: 519-843-6550; E-mail: jkscott@bserv.com

Submission: January 26, 2018

Accepted: February 28, 2018

Published: March 13, 2018

Copyright: @ 2018 Scott JD, et al. This is an open access article distributed under the Creative Commons Attribution License, which permits unrestricted use, distribution, and reproduction in any medium, provided the original work is properly cited.

were studied at Long Point, Ontario in 1972-1973 [15]. In the upper U.S. Midwest, blacklegged tick adults were collected from whitetailed deer, Odocoileus virginianus, before 1970 (U.S. National Tick Collection). Since the home range of white-tailed deer extends into southern Manitoba and northwestern Ontario northward to the $52^{\circ}$ latitude, these cervids would have been crossing back and forth across the Canada-U.S. border ad infinitum transporting I. scapularis ticks.

Every spring, migratory birds fly to Canada's northland to breed, nest, and raise their young in the boreal forest. En route, groundforaging passerines (Passeriformes) make stop-overs in Lyme disease endemic areas, and are parasitized by ixodid ticks [16]. Using futuristic projection models, certain researchers posit that blacklegged ticks are incrementally moving north due to climate change [17]. However, other researchers have already documented Lyme disease vector ticks, including I. scapularis, as far west and as far north as northern Alberta and the Yukon, dating back to 1998 [18-20].

The aim of this study is to assess the various aspects that affect the incidence of Lyme disease in Canada, and determine the overriding factors that affect the adaptability and distribution of I. scapularis in Canada.

\section{Materials and Methods}

In order to carry out our 5-yr overwinter study (winters of 20132017), we sourced the I. scapularis adults each fall by flagging a Lyme disease endemic area. The overwintering tick housing unit, which contained these live I. scapularis adults, was set out in a wooded area with well-drained soil and gently sloping topography $\left(43^{\circ} 42^{\prime} \mathrm{N} ; 80^{\circ}\right.$ $22^{\prime} \mathrm{W}$ ). The plywood and white pine housing unit contained a vented, plastic canister $(63 \mathrm{~mm} \times 135 \mathrm{~mm})$ to hold the vented polyethylene vials each containing 2-5 blacklegged tick adults (Figure 1). The canister was covered with aluminum screen for mouse exclusion. The screened canister was then put in an open-ended housing unit $(80 \mathrm{~mm} \times 125 \mathrm{~mm} \times 150 \mathrm{~mm})$ for hoof protection. In the fall, the housing unit, which contained the screened canister, was placed on the soil surface, and covered with a layer of leaves to replicate the surrounding leaf layer. A couple of dead limbs were placed in juxtaposition to the housing unit to keep leaves from being blown away. In the following spring, the housing unit was collected, and the ticks were counted. Local outdoor temperatures were obtained from Environment Canada. 


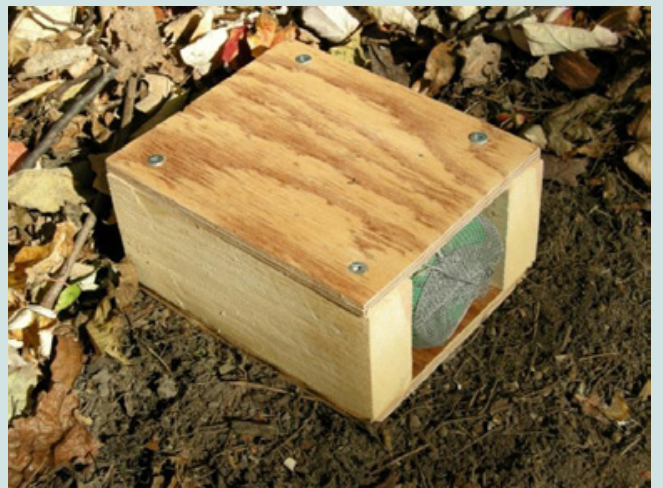

Figure 1: Housing unit for overwinter study of $I$. scapularis adults.

\section{Results}

Our 5-yr study reveals that when there was consistent snow cover, $\geq 90 \%$ of the I. scapularis adults overwintered successfully (Table 1). However, when the winter temperatures were warmer, and the snow completely melted, overwinter survival dropped significantly. In the winter of 2016-2017, warm daytime temperatures were: Feb. $18\left[15{ }^{\circ} \mathrm{C}\right]$, Feb. $19\left[6{ }^{\circ} \mathrm{C}\right]$, Feb. $20\left[5{ }^{\circ} \mathrm{C}\right]$, Feb. $21\left[6{ }^{\circ} \mathrm{C}\right]$, Feb. 22 [13 $\left.{ }^{\circ} \mathrm{C}\right]$, Feb. $23\left[15{ }^{\circ} \mathrm{C}\right]$; the snow cover disappeared completely in the woodlot. Then, without snow cover, there was a series of subzero night-time temperatures: Mar. $3\left[-11^{\circ} \mathrm{C}\right]$, Mar. $4\left[-13^{\circ} \mathrm{C}\right]$, Mar. $5[-14$ $\left.{ }^{\circ} \mathrm{C}\right]$. Because of these exquisitely cold temperatures, only 10/30 (33\%) of the I. scapularis adults survived the winter.

This winter hardiness study shows that snow cover is vitally important for the overwinter survival of I. scapularis in Canada. If warm, mid-winter temperatures completely melt the snow, and overnight temperatures drop quickly to $-3{ }^{\circ} \mathrm{C}$ or lower, this sudden chill factor can be lethal to I. scapularis ticks. In actuality, warm winters work against overwinter survival of blacklegged ticks because the number of live ticks is markedly reduced in northern climes when the snow completely melts (Table 1).

\section{Discussion}

Our overwinter study reveals that warm winters decrease survival of I. scapularis ticks. With the exception of overwinter temperatures, all environmental factors (i.e. housing unit, leaf cover, site location) were the same each winter. In year 5 (2016-2017), the snow was totally lost in February due to warm temperatures and, then, I. scapularis adults were exposed to frigid, overnight temperatures. Although the ticks were in vented vials, ticks would naturally be trapped above ground by the sudden overnight freezing that capped the upper layer of the topsoil. In actuality, warmer winters work against tick expansion.

\section{Snow cover}

Blacklegged ticks go into diapause during the winter in northern latitudes, and reside under an insulating blanket of snow, which plays a key role in the overwinter survival of I. scapularis. In our overwinter experiment, we observed that when warm weather melted the snow cover in February, overwinter survival dropped to 33\%. Our findings are consistent with other researchers who found that overwinter
Table 1: Overwinter survival of Ixodes scapularis adults in southern Canada.

\begin{tabular}{|c|c|c|c|c|c|c|c|}
\hline \multirow{2}{*}{ Winter } & \multirow{2}{*}{$\begin{array}{c}\text { No. Ticks } \\
\text { Set Out }\end{array}$} & \multicolumn{2}{|c|}{ No. Survived } & \multirow{2}{*}{$\begin{array}{l}\text { Overwinter } \\
\text { Survival (\%) }\end{array}$} & \multirow{2}{*}{$\begin{array}{l}\text { Lowest } \\
\text { Temp ('C) }\end{array}$} & \multirow{2}{*}{$\begin{array}{l}\text { Accumulated } \\
\text { Snow Cover } \\
\text { (cm) }\end{array}$} & \multirow{2}{*}{$\begin{array}{l}\text { Snow } \\
\text { Depth }\end{array}$} \\
\hline & & Males & Females & & & & \\
\hline $\begin{array}{l}2012- \\
2013\end{array}$ & $\begin{array}{c}23(11 \mathrm{M}, \\
12 \mathrm{~F})\end{array}$ & 10 & 11 & $21 / 23(91)$ & $\begin{array}{l}-23 \text { [24 } \\
\text { January] }\end{array}$ & 43 & $\csc$ \\
\hline $\begin{array}{l}2013- \\
2014\end{array}$ & $\begin{array}{c}20(10 \mathrm{M}, \\
10 \mathrm{~F})\end{array}$ & 9 & 10 & $19 / 20(95)$ & $\begin{array}{c}-31 \text { [12 } \\
\text { February] }\end{array}$ & 71 & $\csc$ \\
\hline $\begin{array}{l}2014- \\
2015\end{array}$ & $\begin{array}{c}20(10 \mathrm{M}, \\
10 \mathrm{~F})\end{array}$ & 9 & 9 & $18 / 20(90)$ & $\begin{array}{c}-35[16 \\
\text { February] }\end{array}$ & 56 & $\csc$ \\
\hline $\begin{array}{l}2015- \\
2016\end{array}$ & $\begin{array}{c}14(5 \mathrm{M}, \\
9 \mathrm{~F})\end{array}$ & 5 & 8 & $13 / 14(93)$ & $\begin{array}{c}-21 \text { [18 } \\
\text { February] }\end{array}$ & 63 & $\csc$ \\
\hline $\begin{array}{l}2016- \\
2017\end{array}$ & $\begin{array}{c}30(15 \mathrm{M}, \\
15 \mathrm{~F})\end{array}$ & 2 & 8 & $10 / 30(33)$ & $\begin{array}{c}-20[7 \\
\text { January] }\end{array}$ & $0 \dagger$ & NSC \\
\hline
\end{tabular}

F: Females; M: Males; CSC: Consistent Snow Cover; NSC: No Snow Cover because it melted prematurely

† Loss of snow covers resulting from a warm spell with ambient air temperatures reaching $+15^{\circ} \mathrm{C}$ [18 February, 23 February].

survival of I. scapularis females at Long Point, Ontario decreased due to lack of snow cover [21]. As well, Brunner et al. found that blacklegged ticks are sensitive to cold threshold temperatures [22]. In addition our results are consistent with Vandyk et al. who found that brief exposure to extreme cold temperatures $\left(-13^{\circ} \mathrm{C}\right)$ for $8 \mathrm{~h}$ can be lethal to blacklegged ticks, especially unfed adults and engorged larvae [23], which exhibit the least cold hardiness. Warmer winters, which prematurely melt the snow cover, decrease overwinter survival of $I$. scapularis in northern climes because sudden frigid temperatures caused death due to direct chilling injury [24]. When the snow completely melted, and sub-zero temperatures suddenly froze the upper humus layer, a sheet of ice capped the soil surface. Consequently, ticks became trapped above ground. Despite what some researchers claim, warmer winters ultimately leave ticks overexpose to frigid temperatures, and overwinter survival decreases significantly. Our overwinter experiment provides a straightforward way to show that warm temperatures and the absence of snow cover dramatically reduces the survival of I. scapularis in northern latitudes.

\section{Climate change and songbirds}

The perceived effect of climate change on ticks and Lyme disease has become a controversial issue. DellaSala et al. claims that the spread of Lyme disease is due to an unprecedented accumulation of air pollution and climate change [25]. Moreover, Ogden et al. speculates that climate change will induce northward tick expansion of blacklegged ticks in Canada [17], and propagate Lyme disease numbers, but their hypotheses are unsubstantiated. In actuality, the overriding factor in the wide dispersal of $I$. scapularis and $B$. burgdorferi in Canada are migratory songbirds [16,18-20,26]. Not only are ground-foraging passerine migrants involved with the wide dispersal of immature stages of I. scapularis, raptors are also dispersing agents [27]. In central and eastern Canada, Scott and Durden found that $35 \%$ of the songbird-transported I. scapularis nymphs were infected with $B$. burgdorferi, and widely dispersed in nature [26]. Although global warming is claimed to be one of the contributing factors for enzootic B. burgdorferi transmission and tick expansion, migratory songbirds are actually the principal reason. What may be perceived as tick expansion brought on by climate change is actually yearly bidirectional, songbird migration in spring and fall. In addition, songbirds that are heavily infested with ticks can also start new foci of I. scapularis ticks on islands or remote mainland areas [28-30]. 
Ogden et al. indicates that model-derived, temperature limits for I. scapularis establishment [17], projected for the 2080s, overlap the core migratory flight path for Neotropical and southern-temperate songbirds heading to their breeding grounds in the Yukon [17]. This climate change model actually reflects current migratory flight, not warmer futuristic temperatures. In addition, other researchers have already documented Lyme disease vector ticks in the Yukon $[16,20]$. What appears to be sequentially warmer weather in the northern part of the Prairie Provinces, is actually the ongoing flight path of spring migratory songbirds heading to the northwest part of the boreal forest. As expected, these spring migrants drop I. scapularis immature at stopovers along this well established migratory flight path.

\section{Photoperiod limitation for I. scapularis}

Ticks have a assemblage of peripheral sensory organs, including photosensilla, that monitor the external environment, especially visible light [31]. When the light impinges on the photoreceptor neurons, ticks respond to variations in light intensity, and modify their behaviour accordingly. The blue light in the sunlight spectrum regulates the internal body clock that activates photosensitive receptor cells, and triggers whether a fully engorged larva or nymph will molt to the next life stage at the proper time or, in the case of a fully engorged female, will lay eggs in the spring.

The daily photoperiod is one of the inherent factors in the development of blacklegged ticks. In northern latitudes, photoperiod decreases quickly in mid-summer above $52^{\circ}$ latitude, and physiological development of I. scapularis is hampered especially for molting and egg laying. Using time-lapse models, climate change researchers forecast I. scapularis establishment in northern parts of the Prairie Provinces [17]; however, the photoperiod shortens quickly in midsummer, and is too short for I. scapularis establishment. Although they predict that $I$. scapularis will move $1000 \mathrm{~km}$ further north by the 2080s, the daylength is too short for I. scapularis immatures to molt to the next developmental life stage. These authors overlook the limitations of accelerated shorten photoperiod in August. Regardless of any potential climate change, the photoperiod is a critical, limiting factor for larval emergence and development. Songbird-transported $I$. scapularis immatures will molt successfully in late May when dropped, but I. scapularis larvae, which hatch from eggs, will encounter daylength barriers in August due to a rapid decrease in photoperiod in northern latitudes. Based on our in-house tick studies, we reveal that replete I. scapularis immatures require 14 hours of daylight to molt to the next developmental life stage. Notably, photoperiod is an innate factor that cannot be altered by climate change. The hypothesis that I. scapularis ticks will expand further north in the Prairie Provinces because of climate change is not only unscientific, but deceiving.

Photoperiod is critically important for the survival and establishment of I. scapularis ticks. For example, I. scapularis ticks are not established in the Neotropics where the temperature is consistently warmer. If, in fact, warmer temperatures were a contributing factor in I. scapularis tick expansion, they would become established in mesoAmerica and the northern part of South America, but, in fact, they have not established in this warmer zoogeographic region [32,33]. Even though I. scapularis have the potential to move south where temperatures are warmer, they encounter reduced daylight. At the equator, where temperatures are the warmest, and the photoperiod is closely balanced between day and night, there is no establishment of $I$. scapularis. Notably, Amblyomma ticks are the predominant genus in the Neotropics [33]. Regardless of potentially warmer temperatures in Canada in northern regions, I. scapularis are limited to how far north they can establish due to photoperiod. In northern latitudes of Canada, short daytime photoperiods becomes a limiting factor for $I$. scapularis establishment.

\section{Blacklegged ticks are eco-adaptive}

The historical mean daily temperatures for central Canada over the past 80 years have increased $<0.5{ }^{\circ} \mathrm{C}$ (Environment Canada). And yet, at Kenora, Ontario, all post-embryonic developmental life stages of I. scapularis have withstood temperatures ranging between $+36{ }^{\circ} \mathrm{C}$ and $-44{ }^{\circ} \mathrm{C}$, a differential of $80{ }^{\circ} \mathrm{C}[3,34]$. On hot summer days, blacklegged ticks descend into the cool, moist leaf litter, and rehydrate. In winter, they are comfortable in the humus layer under an insulating blanket of snow. In addition, they have antifreezelike compounds (glycoproteins) in their bodies that allow them to overwinter successfully [35]. Whenever ticks are under any climate stress, they commonly find a suitable microhabitat. If the female felt the stress of extinction from high ambient temperatures, she would lay more eggs, and there would be more ticks. However, she is in a cool, moist microhabitat where she has always been for millennia and, therefore, will not lay more eggs. Blacklegged ticks have an innate ability to survive phenomenal temperature fluctuations, especially when there is an insulating blanket of snow. Therefore, it is highly unlikely that climate warming is ever going to be a driver for $I$. scapularis expansion.

\section{Blacklegged ticks are survivors}

The history of ticks goes back millions of years. Oddly enough, certain researchers profess that changes in temperature, precipitation, and humidity have a huge impact on Lyme disease transmission [25]. Prehistorically, an extant Borrelia species has been detected in a fossilized Amblyomma tick collected from a Dominican Republic amber mine dating back 15-20 mya [36]. In North America, Borrelia burgdorferi sensu stricto dates back more than 20,000 years [37]. Of course, these Borrelia microorganisms had vectors and reservoirs to endure the environmental changes. Despite dramatic shifts in temperature, precipitation, and humidity, borrelial spirochetes have survived extreme weather variables over millions of years. They were present during prehistoric times, and they are still present today. Likewise, Amblyomma ticks, which harbor Babesia species, have survived 20-30 mya despite many shifts in climate change [38]. Despite an $0.5{ }^{\circ} \mathrm{C}$ increase in historical mean daily temperatures in central Canada over 80 years, Borrelia and Babesia species and their associated vectors have handily adapted to many shifts in climate change.

\section{Climate change projections}

Several medical and governmental organizations have touted climate change as the reason for an increase in Lyme disease. Similarly, certain climate researchers assert that environmental conditions will be more favourable for I. scapularis to move northward from the upper U.S. Midwest into Canada [25], but their claims are ambiguous and yet, other tick researchers have already reported songbird-transported I. scapularis immatures, dating back to 1998, in northern Alberta 
$[18,19]$. In addition, Scott et al. reported an established population of I. scapularis on Corkscrew Island, near Kenora, Ontario [34], with an infection prevalence of $73 \%$ for $B$. burgdorferi. This high prevalence of Lyme disease spirochetes indicates that ticks have been there all along, and simply overlooked. It is noteworthy that the B. burgdorferi infection prevalence in an established population of $I$. scapularis gradually increases with time. For example, at Point Pelee National Park, the B. burgdorferi prevalence before 2000 was nil [39]; however, by 2012 , it had increased in a seesaw, staccato manner to $27.4 \%$ [40]. Since the B. burgdorferi infection prevalence typically increases with time, the establishment of I. scapularis on Corkscrew Island predates Long Point. Ecologically, the relative abundance of I. scapularis at a site will likewise increase incrementally over decades [41]. This temporal pattern acts as a reputed guide to date the establishment of I. scapularis populations.

Brownstein et al. used a climate-based suitability model to forecast the effect of climate change on I. scapularis expansion in Canada [42]. These authors assumed that established populations of blacklegged ticks were limited to a small number of foci in southern Ontario, but their assertions are unverifiable. They overlooked the fact that $I$. scapularis ticks were already established in northwestern Ontario and, likewise, in southern Manitoba. Ironically, blacklegged ticks were already in central Canada prior to 1970 [34]. Since the benchmark parameters are incorrect, forecasts of a $213 \%$ increase in I. scapularis foci further north in Canada by the 2080s [42], are misleading. Moreover, any studies on ticks and climate change have been inconclusive.

Simon et al. predicted northward expansion for B. burgdorferi of $\sim 250-500 \mathrm{~km}$ by 2050 in Canada [43]. To counterpoise, other researchers show that passerine migrants perpetually transport birdfeeding ticks to the breeding grounds in the boreal forest $[18,20]$. For instance, Scott et al. previously reported a $B$. burgdorferi-positive $I$. scapularis nymph in central Saskatchewan during northward spring migration [16]. As well, other researchers have reported larval and nymphal $I$. scapularis ticks on long- and short-distance songbirds $[28,44]$. What some climate change researchers have been projecting for the future has already taken place across Canada prior to 1970 . For blacklegged ticks, climate change is an apocryphal issue.

\section{Discovery of blacklegged tick populations}

Some climate change authors arbitrarily perceive that $I$. scapularis ticks and tick-borne diseases expand northward due to climate change $[17,25,42,45,46]$. East Coast researchers examined many environmental factors, and found that there was only a weak correlation between total density of I. scapularis nymphs and several climate variables [47]. Initial I. scapularis studies in Canada were conducted on the north shore of Lake Erie, and Canadian researchers had no other direction to advance than to move further north. Using time-lapse mapping, climate change researchers produced a series of time-lapse maps showing the pre-supposed northward advancement of I. scapularis in Canada [46]. Although the benchmark map had no evidence of $I$. scapularis in northwestern Ontario, established populations were already in place, and simply overlooked by climate change researchers. Therefore, the initial phase of the simulation model, which was generated by researchers for I. scapularis, consequently skewed the rate of tick expansion and miscalculated the projected northward movement of I. scapularis in Canada [46]. When the progression of climate change studies was examined, the pattern seemed to fit well with the climate change hypothesis. However, superimposing a climate change model overtop a map of when I. scapularis populations were studied is not only confusing but disingenuous.

\section{Northward expansion of ticks and white-footed mice}

The northward expansion of Lyme disease spirochetes, ticks and white-footed mice in Canada due to climate change is highly speculative. Roy-Dufresne et al. contend that warmer winters will advance the northward movement of white-footed mice [48], Peromyscus leucopus, nearly $3^{\circ}$ latitude by 2050 , and maintain earnestly that the distribution of these cricetid rodents are a critical factor in identifying future areas at risk of Lyme disease. And yet, Scott et al. documented an established population of I. scapularis on Corkscrew Island in northwestern Ontario, and there are no whitefooted mice [34]. Likewise, there are multiple established populations of I. scapularis in Manitoba, but there are no white-footed mice in this province [43]. The significance of any shift in the home range of whitefooted mice is myopic because other small mammals, such as deer mice, Peromyscus maniculatus, are indigenous countrywide, and are reservoir hosts for B. burgdorferi. Moreover, Scott et al. documented B. burgdorferi in 8 species of ticks in the Kenora area [3]. Since other mammals and birds are reservoir-competent hosts, the projected northward expansion of white-footed mice is inconsequential.

Ogden et al. hypothesized that climate warming will have a profound effect on vectors and vector-borne diseases [46], and will make climatically unsuitable regions more conducive to $I$. scapularis establishment. In contrast, Scott et al. clearly show that the establishment of I. scapularis on Corkscrew Island has nothing to do with climate change [34]. This insular Lyme disease endemic area was established more than 50 years earlier. Even though this hyperendemic area is devoid of white-footed mice, $B$. burgdorferi perpetually cycles enzootically between reservoir hosts and I. scapularis ticks.

\section{Study time vs. I. scapularis establishment}

Pioneer tick identifier, Thomas Say, studied and named $I$. scapularis in 1821; however, the origin of this tick species in North America likely goes back several millennia. Just because an $I$. scapularis population was studied in a certain year, does not mean that this timeframe is when it became established. In fact, the progression of studies on I. scapularis in eastern and central Canada used by several researchers $[17,45,46]$, simply follows the order in which they were conducted, not the result of climate change. For instance, researchers initially studied an established population of $I$. scapularis in northeastern U.S.A. in the early 1980s [28,49]. However, recent genetic studies reveal that I. scapularis populations in that area go back 20,000 years [37]. Since Lyme, Connecticut and Long Point, Ontario are approximately on the same latitude, and both locations are within the same biogeographical area, the I. scapularis population at Long Point, Ontario could well have become established soon after the last ice age approximately 10,000 years ago.

Furthermore, the benchmark model, which was generated by climate change researchers, shows the establishment of I. scapularis at Pembroke, Ontario and Parry Sound, Ontario. In contrast, the 
Lyme disease risk map shows no evidence of any risk areas at these geographical locations [50]. The time-lapse model sharply conflicts with the actual areas designated as Lyme disease foci. Such models contradict field data, and misrepresent the Lyme disease timeline of tick establishment in Canada.

Leighton et al. allege that $I$. scapularis has expanded its range northward during the past two decades [51], from the United States, to colonize new regions of Canada. However, they admit to not knowing the extent to which the actual tick range expansion transpired. Just south of the Canada-U.S. border, records of $I$. scapularis date back to the late 1960s in the upper Midwest (U.S. National Tick Collection). In addition, researchers discovered $I$. scapularis larvae and an I. scapularis nymph on small mammals (i.e. red-backed voles, deer mice) at Marchand, Manitoba in 1991, and these two immature stages constitute an established population $[52,53]$. Furthermore, adult I. scapularis were collected at the same location and, collectively, all 3 mobile life stages (adult, nymph, larva) represent a reproducing population. These discoveries were not taken into account on the climate change model maps [17,42,45, 46,51]. Likewise, four I. scapularis ( 2 females, 1 male, 1 nymph) were collected on 12 May and 9 June 1993 from untravelled mammalian hosts (dog, human) residing on the rural property bordering Lake of the Woods north of Rainy River, Ontario; one of the 3 adults was positive for B. burgdorferi [54]. All together, these tick collections constitute an established population of I. scapularis [53]. These epidemiological findings were overlooked on the climate change maps $[17,42,45,46,51]$. Furthermore, game hunters, who are now seniors, remember ticks on the heads and necks of white-tailed deer during the 1950s and 1960s in northwestern Ontario and southern Manitoba. What some climate change researchers charted as being absent of I. scapularis on their benchmark maps were, in fact, already there.

Researchers prognosticated that $80 \%$ of the human population in eastern and central Canada will be inhabiting areas at risk of Lyme disease by 2020 [51]. However, only $2.5 \%$ of Ontario currently has Lyme disease risk areas [50], so these climate change projections and associated climate change maps have subtle scientific shortfalls.

\section{Migratory songbirds transport ticks and introduce tick-borne} pathogens

The blacklegged tick is known to carry at least 10 different tickborne pathogens [34]. For example, Scott reported the first locally acquired case of human babesiosis caused by Babesia duncani in Canada [55]; the patient was bitten by an I. scapularis nymph. Based on an archaeological study in the Dominican Republic, Poinar detected a Babesia-like piroplasm in a fossilized Amblyomma tick encased in amber [38]. This prehistoric discovery indicates that these intraerythrocytic hemoparasites, along with their tick vectors, have survived 15-45 mya, irrespective of dramatic shifts in temperature and climate change.

Despite any climate change, $B$. duncani is likely being introduced into Canada by songbird-transported ticks passerine migrants during spring migration (Figure 2). Hersh et al. documented 3 tick-borne pathogens (i.e. Borrelia burgdorferi [56], Babesia microti, Anaplasma phagocytophilum) in a songbird-transported I. scapularis nymph

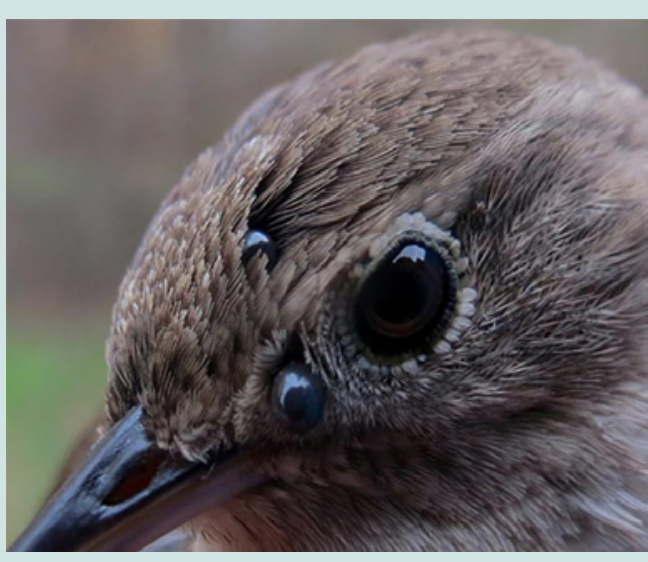

Figure 2: House Wren, Troglodytes aedon, parasitized by Ixodes scapularis nymphs during northward spring migration. One of these nymphs was infected with the Lyme disease bacterium, Borrelia burgdorferi.

removed from a Veery, Catharus fuscescens. Because migratory birds transport blacklegged tick larvae and nymphs hundreds of kilometres during northward migratory flight, they are important epidemiological drivers for the wide dispersal of I. scapularis ticks and tick-associated pathogens.

Neotropical songbirds transport ticks from as far south as Brazil into Canada during northward spring migration. Some of these ground-frequenting passerine migrants are parasitized by Amblyomma ticks (A. americanum, A. dissimile, A. longirostre, A. maculatum, A. rotundatum), and dispersed across Canada [16,5759]. Although the larvae of these Neotropical Amblyomma ticks do not overwinter in Canada, they are transported into Canada. Not only do passerine migrants transport Amblyomma ticks hundreds of kilometres into Canada during spring migration, they commonly transport Ixodes spp. ticks (I. auritulus, I. brunneus, I. dentatus, I. muris, I. pacificus, I. scapularis, I. spinipalpis) [16,18-20,57]. The presence of Amblyomma spp. on Neotropical songbirds confirms importation of bird-feeding ticks. If, in fact, there was any substantive climate warming, Amblyomma americanum (lone star tick) would have become established in the southernmost part of Ontario, but they haven't. Even though songbird-transported A. americanum immatures molt to the next life stage and parasitize domestic animals and humans in August, they have not become established in Canada.

\section{Public awareness reflects tick numbers}

Certain researchers predict an alarming spread of Lyme disease resulting in enormous consequences to humanity due to unprecedented climate change [25]. These authors also contend that conditions are improving for disease transmission; however, these spurious contentions are unsubstantiated. Transmission typically depends on several factors: whether the tick is infected and, hence, whether the tick has vector competence. Based on epidemiological I. scapularis studies, East Coast researchers conclude that any link between climate change, ticks, and tick-borne diseases is provisional and cast in doubt [60].

According to some researchers temperature and humidity in the early spring and autumn are important drivers of tick populations [25]; however, there is no evidence to support this postulate. Schulze et al. 
Citation: Scott JD, Scott CM. Lyme Disease Propelled by Borrelia burgdorferi-Infected Blacklegged Ticks, Wild Birds and Public Awareness - Not Climate Change. J Veter Sci Med. 2018;6(1): 8

found that temperature and precipitation during the questing period of I. scapularis larvae and nymph had no bearing on the abundance of nymphs [61]. During inclement weather, these ixodid immatures recess to a cooler, moist microhabitat in the humus layer and topsoil. Climate change researchers predict that I. scapularis populations will expand northward $200 \mathrm{~km}$ by the 2020s and 1,000 km by 2080 in Canada [17]. And yet, public awareness and human cases have actually played a far greater role in the number of ticks submitted for identification and testing [54]. As people become more aware of ticks and tick-borne diseases, they perceive there is an increase in numbers. Importantly, what actually propels public awareness is outdoors people finding ticks on their pets and themselves, and having them identified and tested for tick-transmitted pathogens. The escalation of more ticks being submitted each year is actually due to increased public awareness and human Lyme disease cases.

Spurious climate change forecasts can easily be misrepresent in time-lapse models. Ultimately, the climate change models actually reflect the order in which established populations of I. scapularis were studied in Canada. After the first studies at Long Point [15], Point Pelee National Park [39], Rondeau Provincial Park [62,63], and Turkey Point $[64,65]$, the only direction for future study was to move further north in Canada. Based on these first Canadian studies, several authors presumed that the year 1970 would make a good benchmark to base projected climate change models $[17,42,45,46,51]$. However, they overlooked the fact that established populations already existed for decades, centuries, or perhaps millennia at northern latitudes. In nature, there are too many biotic and abiotic variables to draw any firm conclusions that would authenticate a link between tick expansion and climate change. When it comes to ticks, climate change is a insignificant.

In conclusion, blacklegged ticks have a innate ability to adapt to southern Canada's year-round weather and, with adequate snow cover in winter, adjust to phenomenal temperature fluctuations. Our findings reveal that warmer winters actually impede winter survival of blacklegged ticks. Photoperiod is critically important in determining whether blacklegged ticks can establish in northern Canada. Rather than climate change, public awareness and human cases is actually the putative gauge in representing the epidemiology of I. scapularis ticks and Lyme disease. Although climate warming has been considered a factor in the northward movement of I. scapularis, migratory songbirds are the overriding factor in transporting I. scapularis to northern latitudes. With respect to blacklegged ticks, climate change is a triviality. Regardless of any perceived climate warming, health practitioners must be cognisant that Lyme disease-carrying ticks may be present in their area, and present a public health risk.

\section{References}

1. Burgdorfer W, Barbour AG, Hayes SF, Banach JL, Grunwaldt E, et al. (1982) Lyme disease-a tick-borne spirochetosis? Science 216: 1317-1319.

2. Scott JD, Durden LA, Anderson JF (2015) Infection prevalence of Borrelia burgdorferi in ticks collected from songbirds in far-western Canada. Open $\mathrm{J}$ An Sci 5: 232-241.

3. Scott JD, Clark KL, Anderson JF, Foley JE, Young MR, et al. (2017) Lyme disease bacterium, Borrelia burgdorferi sensu lato, detect in multiple tick species at Kenora, Ontario, Canada. J Bacteriol Parasitol 8: 304.
4. Keirans JE, Hutcheson HJ, Durden LA, Klompen JS (1996) Ixodes (Ixodes) scapularis (Acari: Ixodidae): redescription of all active stages, distribution, hosts, geographical variation, and medical and veterinary importance. J Med Entomol 33: 297-318.

5. Berger BW (1989) Dermatologic manifestations of Lyme disease. Rev Infect Dis 11 (Suppl 6): S1475-S1481.

6. Stonehouse A, Studdiford JS, Henry CA (2010) An update on the diagnosis and treatment of early Lyme disease: "focusing on the bull's eye, you may miss the mark". J Emer Med 39: e147-e151.

7. Johnson L, Wilcox S, Mankoff J, Stricker RB (2014) Severity of chronic Lyme disease compared to other chronic conditions: a quality of life survey. Peer J 2: e322.

8. Forrester JD, Meiman J, Mullins J, Nelson R, Ertel SH, et al. (2014) Notes from the field: update on Lyme carditis, groups at high risk, and frequency of associated sudden cardiac death--United States. Morb Mortal Wkly Rep 63: 982-983.

9. Weber K, Neubert U, Buchner SA (1993) Erythema migrans and early signs and symptoms. In: Weber K, Burgdorfer W, (Eds). Aspects of Lyme borreliosis. Springer-Verlag, Berlin, Germany, pp. 105-121.

10. Masters EJ, Donnell D, Fobbs M (1994) Missouri Lyme disease: 1989 through 1992. J Spir Tick-borne Dis 1: 12-17.

11. Price GE, Banerjee SN (1995) Case reports: Lyme arthritis in British Columbia. J Spir Tick-borne Dis 2: 52-54.

12. Schutzer SE, Berger BW, Krueger JG, Eshoo MW, Ecker DJ, et al. (2013) Atypical erythema migrans in patients with PCR-positive Lyme disease. Emerg Infect Dis 19: 815-817.

13. Cameron DJ, Johnson LB, Maloney EL (2014) Evidence assessments and guideline recommendations in Lyme disease: the clinical management of known tick bites, erythema migrans rashes and persistent disease. Expert Rev Anti Infect Ther 12: 1103-1135

14. Nuttall GH, Warburton C (1911) Ixodidae. Section II. The genus Ixodes. In: Nuttall GH, Warburton C, Cooper WF, Robinson LE (Eds). Ticks A Monograph of the Ixodoidea, Part II. Cambridge University Press, London, United Kingdom, pp. 133-203.

15. Watson TG, Anderson RC (1976) Ixodes scapularis say on white-tailed deer (Odocoileus virginianus) from Long Point, Ontario. J Wildl Dis 12: 66-71.

16. Scott JD, Anderson JF, Durden LA (2012) Widespread dispersal of Borrelia burgdorferi-infected ticks collected from songbirds across Canada. J Parasitol 98: 49-59.

17. Ogden NH, Maarouf A, Barker IK, Bigras-Poulin M, Lindsay LR, et al. (2006) Climate change and the potential for range expansion of the Lyme disease vector Ixodes scapularis in Canada. Int J Parasitol 36: 63-70.

18. Scott JD, Fernando K, Banerjee SN, Durden LA, Byrne SK, et al. (2001) Birds disperse ixodid (Acari: Ixodidae) and Borrelia burgdorferi-infected ticks in Canada. J Med Entomol 38: 493-500.

19. Morshed MG, Scott JD, Fernando K, Beati L, Mazerolle DF, et al. (2005) Migratory songbirds disperse ticks across Canada, and first isolation of the Lyme disease spirochete, Borrelia burgdorferi, from the avian tick, Ixodes auritulus. J Parasitol 91: 780-790.

20. Scott JD, Lee MK, Fernando K, Durden LA, Jorgensen DR, et al. (2010) Detection of Lyme disease spirochete, Borrelia burgdorferi sensu lato, including three novel genotypes in ticks (Acari: Ixodidae) collected from songbirds (Passeriformes) across Canada. J Vect Ecol 35: 124-139.

21. Lindsay LR, Barker IK, Surgeoner GA, McEwen SA, Gillespie TJ, et al. (1995) Survival and development of Ixodes scapularis (Acari: Ixodidae) under various climatic conditions in Ontario, Canada. J Med Entomol 32: 143-152.

22. Brunner JL, Killilea M, Osfeld RS (2012) Overwintering survival of nymphal Ixodes scapularis (Acari: Ixodidae) under natural conditions. J Med Entomo 49: 981-987.

23. Vandyk JK, Bartholomew DM, Rowley WA, Platt KB (1996) Survival of Ixodes scapularis (Acari: Ixodidae) exposed to cold. J Med Entomol 33: 6-10. 
Citation: Scott JD, Scott CM. Lyme Disease Propelled by Borrelia burgdorferi-Infected Blacklegged Ticks, Wild Birds and Public Awareness - Not Climate Change. J Veter Sci Med. 2018;6(1): 8

24. Burks CS, Stewart Jr RL, Needham GR, Lee Jr RE (1996) The role of direct chilling injury and inoculative freezing in cold tolerance of Amblyomma americanum, Dermacentor variabilis and Ixodes scapularis. Physiol Entomol 21: $44-50$.

25. DellaSala DA, Middelveen M, Liegner KB, Luche-Thayer J (2017) Lyme disease epidemic increasing globally due to climate change and human activities. In: DellaSala DA, Goldstein M, (Eds). Encyclopedia of the anthropocene, (1 ${ }^{\text {st }}$ edn). Philadelphia, St. Louis, New York, U S A, pp. 441 451.

26. Scott JD, Durden LA (2015) New records of the Lyme disease bacterium in ticks collected from songbirds in central and eastern Canada. Int $\mathrm{J}$ Acaro 41: 241-249.

27. Scott JD, Foley JE, Young MR, Durden LA (2017) First report of a blacklegged tick, Ixodes scapularis Say (Acari: Ixodidae), parasitizing a raptor in Canada Syst Appl Acarol 22: 208-216.

28. Anderson JF, Magnarelli LA (1984) Avian and mammalian hosts for spirochete-infected ticks and insects in a Lyme disease focus in Connecticut. Yale J Biol Med 57: 627-641.

29. Anderson JF, Magnarelli LA, Stafford $3^{\text {rd }}$, KC (1990) Bird-feeding ticks transstadially transmit Borrelia burgdorferi that infect Syrian hamsters. J Wild Dis $26: 1-10$

30. Scott JD, Scott CM, Anderson JF (2014) The establishment of a blacklegged tick population by migratory songbirds in Ontario, Canada. J Veter Sci Med 2: 5

31. Ladislav S, Sonenshine DE, Park Y, Zitnan, D (2014) Nervous and sensory systems: structure, function, genomics, and proteomics. In: Sonenshine DE, Roe RM, (Eds). Biology of ticks, ( $\left.2^{\text {nd }} e d n\right)$, Oxford University Press, New York U S A, pp. 309-367.

32. Durden LA, Keirans JE (1996) Nymphs of the genus Ixodes (Acari: Ixodidae) of the United States: taxonomy, identification key, distribution, hosts, and medical/veterinary importance. Entomological Society of America, Lanham, Maryland, U S A, pp. 95.

33. Jones EK, Clifford CM, Keirans JE, Kohls GM (1972) The ticks of Venezuela (Acarina: Ixodoidea) with a key to the series of Amblyomma in the Western Hemisphere. Brigham Young University Science Bulletin, Biological Series 17: $01-47$

34. Scott JD, Foley JE, Clark KL, Anderson JF, Durden LA, et al. (2016) Established population of blacklegged ticks with high infection prevalence for the Lyme disease bacterium, Borrelia burgdorferi sensu lato, on Corkscrew Island, Kenora District, Ontario. Int J Med Sci 13: 881-891.

35. Heisig M, Abraham NM, Liu L, Neelakanta G, Mattessich S, et al. (2014) Antivirlence properties of an antifreeze protein. Cell Rep 9: 417-424.

36. Poinar G Jr (2015) Spirochete-like cells in a Dominican amber Amblyomma tick (Arachnida: Ixodidae). Historical Biol 27: 565-570.

37. Walters KS, Carpi G, Caccone A, Diuk-Wasser MA (2017) Genomic insigh into the ancient spread of Lyme disease across North America. Nature Ecol Evol 1: 1569-1576.

38. Poinar G Jr (2017) Fossilized mammalian erythrocytes associated with a tick reveal ancient piroplasms. J Med Entomol 54: 895-900.

39. Banerjee SN, Morshed MG, Scott JD (2000) Epizootiology of the Lyme disease spirochete, Borrelia burgdorferi in blacklegged ticks, Ixodes scapularis and small mammals at Point Pelee National Park. Point Pelee National Park Library, Parks Canada, Leamington, Ontario.

40. Thorndyke R (2013) Blacklegged tick (Ixodes scapularis) collection for testing for the Lyme disease bacteria (Borrelia burgdorferi) at Point Pelee National Park of Canada, 2012. Point Pelee National Park Library, Parks Canada Leamington, Ontario.

41. Wilson ML (1998) Distribution and abundance of Ixodes scapularis (Acari: Ixodidae) in North America: ecological processes and spatial analysis. J Med Entomol 35: 446-457.

42. Brownstein JS, Holford TR, Fish D (2005) Effect of climate change on Lyme disease risk in North America. Ecohealth 2: 38-46.
43. Simon JA, Marrotte RR, Desrosiers N, Fiset J, Gaitan J, et al. (2014) Climate change and habitat fragmentation drive the occurrence of Borrelia burgdorferi, the agent of Lyme disease, at the northeastern limit of its distribution. Evol Appl 7: 750-764

44. Anderson JF, Johnson RC, Magnarelli LA, Hyde FW (1986) Involvement of birds in the epidemiology of the Lyme disease agent Borrelia burgdorferi. Infect Immun 51: 394-396.

45. Ogden NH, Bigras-Poulin M, O'Callaghan CJ, Barker IK, Lindsay LR, et al. (2005) A dynamic population model to investigate effects of climate on geographic range and seasonality of the tick Ixodes scapularis. Int J Parasitol 35: $375-389$

46. Ogden NH, Radojević M, Wu X, Duvvuri VR, Leighton PA, et al. (2014) Estimated effects of projected climate change on the basic reproductive number of the Lyme disease vector Ixodes scapularis. Environ Health Perspect 122: 631-638.

47. Ostfeld RS, Canham CD, Oggenfuss K, Winchcombe RJ, Keesing F (2006) Climate, deer, rodents, and acorns as determinants of variation in Lymedisease risk. PLoS Biol 4: e145.

48. Roy-Dufresne E, Logan T, Simon JA, Chmura GL, Millien V (2013) Poleward expansion of the white-footed mouse (Peromyscus leucopus) under climate change: implications for the spread of Lyme disease. PLoS ONE 8: e80724.

49. Anderson JF, Magnarelli LA, Burgdorfer W, Barbour AG (1983) Spirochetes in Ixodes dammini and mammals from Connecticut. Am J Trop Med Hyg 12: 818-824

50. Public Health Ontario (2017) Ontario Lyme disease map 2017 estimated risk areas.

51. Leighton PA, Koffi JK, Pelcat Y, Lindsay LR, Ogden NH (2012) Predicting the speed of tick invasion: an empirical model of range expansion for the Lyme disease vector Ixodes scapularis in Canada. J Appl Ecol 49: 457-464.

52. Galloway TD, Christie JE, Sekla L, Stackiw W (1991) Current status of the Lyme borreliosis vector, Ixodes dammini, in Manitoba. Can Dis Wkly Rep 17: 259-260

53. Eisen RJ, Eisen L, Beard CB (2016) County-scale distribution of Ixodes scapularis and Ixodes pacificus (Acari: Ixodidae) in the continental United States. J Med Entomol 53: 349-386.

54. Morshed MG, Scott JD, Fernando K, Geddes G, McNabb A, et al. (2006) Distribution and characterization of Borrelia burgdorferi isolates from Ixodes scapularis and presence in mammalian hosts in Ontario, Canada. J Med Entomol 43: 762-773.

55. Scott JD (2017) First record of locally acquired human babesiosis in Canada caused by Babesia duncani: a case report. SAGE Open Med Case Rep 5.

56. Hersh MH, Ostfeld RS, McHenry DJ, Tibbetts M, Brunner JL (2014) Coinfection of blacklegged ticks with Babesia microti and Borrelia burgdorferi is higher than expected and acquired from small mammal hosts. PLoS One 9 6: e99348.

57. Ogden NH, Lindsay LR, Hanincová, K, Barker IK, Bigras-Poulin M, et al (2008) Role of migratory birds in introduction and range expansion of Ixodes scapularis ticks and of Borrelia burgdorferi and Anaplasma phagocytophilum in Canada. Appl Environ Microbiol 74: 1780-1790.

58. Scott JD, Durden LA (2015) First record of Amblyomma rotundatum tick (Acari: Ixodidae) parasitizing a bird collected in Canada. Syst Appl Acarol 20: 155-161.

59. Scott JD, Durden LA (2015) Amblyomma dissimile Koch (Acari: Ixodidae) parasitizes bird captured in Canada. Syst Appl Acarol 20: 854-860

60. Ostfeld RS, Brunner JL (2015) Climate change and Ixodes tick-borne diseases of humans. Phil Trans R Soc B 370 .

61. Schulze TL, Jordan RA, Schulze CJ, Hung RW (2009) Precipitation and temperature as predictors of the local abundance of Ixodes scapularis (Acari: Ixodidae) nymphs. J Med Entomol 46: 1025-1029. 
Citation: Scott JD, Scott CM. Lyme Disease Propelled by Borrelia burgdorferi-Infected Blacklegged Ticks, Wild Birds and Public Awareness - Not Climate Change. J Veter Sci Med. 2018;6(1): 8.

ISSN: $2325-4645$

62. Morshed MG, Scott JD, Banerjee SN, Fernando K, Mann R, et al. (2000) First isolation of Lyme disease spirochete, Borrelia burgdorferi from blacklegged tick, Ixodes scapularis, collected at Rondeau Provincial Park, Ontario. Can Com Dis Rep 26: 42-44.

63. Morshed MG, Scott JD, Fernando K, Mann RB, Durden LA, et al. (2003) Lyme disease spirochete, Borrelia burgdorferi endemic at epicenter in Rondeau Provincial Park, Ontario. J Med Entomol 40: 91-94.
64. Scott JD, Fernando K, Durden LA, Morshed MG (2004) Lyme disease spirochete, Borrelia burgdorferi, endemic in epicenter at Turkey Point, Ontario. J Med Entomol 41: 226-230.

65. Scott JD, Lee M-K, Fernando K, Jorgensen DR, Durden LA, et al. (2008) Rapid introduction of Lyme disease spirochete, Borrelia burgdorferi sensu stricto, in Ixodes scapularis (Acari: Ixodidae) established at Turkey Point Provincial Park, Ontario, Canada. J Vect Ecol 33: 64-69.

\section{Acknowledgment}

We thank Amanda Green for computer graphics. Funding was provided in part by the Mary Alice Holmes Memorial Foundation. 